\title{
BEHAVIORAL PATTERN OF FRUIT \& VEGETABLE CONSUMERS IN THE 'POLA' (FAIR) SYSTEM IN MONARAGALA DISTRICT IN SRI LANKA
}

\author{
P. J. Jayatillake ${ }^{1}$ and R. P. Mahalianaarachchi ${ }^{2}$
}

\begin{abstract}
The vegetable and fruit production plays a major role in domestic food production in Sri Lankan agricultural sector. In the process of developing the fruit and vegetable sector, it is very useful to consider the needs, preferences and behaviour of consumers. The main objective of this study is to find the behavioral patterns of fruit and vegetable consumers in the "Pola" (fair) system and reasons for such behaviour. This research study was carried out by using a combination of cross sectional survey and case studies due to explanatory nature of the study. A total of 100 consumers were interviewed and four case studies were carried out in Monaragala District. Five fairs were selected from five of 10 Divisional Secretariat Divisions. To statistically analyze the data, frequency distributions and chi-squire tests were used. The majority (77\%) of the consumers of the Pola in the Monaragala District were regular purchasers. The main reason for their preference was low price (40\%) and freshness (34\%). The consumer's main vegetable purchasing market was the Pola (97.9\%) and the next was the village retailer (65.5\%). The consumers' main consideration in buying vegetables and fruits is price (56.8\%). Their next considerations are appearance (52\%), freshness $40 \%$, and nutritive value (42.4\%) respectively. Consumers were interested in both price and quality (appearance, freshness and nutritive value) when they purchase vegetables and fruits at the Pola.
\end{abstract}

Key words: Vegetable and fruit productions, Sri Lanka, Pola, Consumer behaviour

\section{BACKGROUND AND JUSTIFICATION}

The vegetable and fruit sub-sector is the most important in the Sri Lankan agricultural sector after paddy. Vegetable \& fruit are grown throughout the country and in the marketing of these crops, a large number of people such as farmers, collectors, retailers, wholesalers are engaged. An average consumer spends nearly $6 \%$ of his expenditure on vegetables only (Consumer finance survey, 1986/87) thus it is important for the farming community as well as consumers. Vegetables and fruits play a major role for the well being of the consumer. Consumption of vegetables and fruits contribute to an increase in the nutritional level of people. It is, therefore, imperative that adequate quantities of these crops be made available in the markets at affordable prices.

In agricultural oriented developing countries like Sri Lanka, fruit and vegetable marketing caters to the tempo of promoting and sustaining the rural economic development. An efficient marketing system is important for the objectives of price stability, equitable distribution of produce and rapid economic growth. Therefore, fruit and vegetable marketing plays a pivotal role in stimulating production and consumption as well as in accelerating the pace of rural economic development (FAO,1989).

${ }^{1}$ Senior Lecturer, Faculty of Management Studies, Sabaragamuwa University of Sri Lanka, Belihuloya, Sri 33 Lanka

${ }^{2}$ Professor of Agribusiness Management, Faculty of Agricultural Sciences, Sabaragamuwa University of Sri Lanka, Belihuloya, Sri Lanka 
The obvious seasonal fluctuation in the price of many fruits and vegetables is a problem for consumers. Another evidence of ineffective marketing is that this produce is not channeled to outlets where it will be valued. On the other hand, it is not given adequate consideration to the needs, preferences and consumer behavior by the producers and those who involved in marketing (Rupasena, 1999) As a result of this, consumers have to rely on decisions of others and automatically, this underestimates the production and marketing functions of the fruit and vegetable sector.

Monaragala is one of the leading districts in fruit and vegetable production and it is one of the most under developed peripheral districts in Sri Lanka. The land area of the Monaragala District is 5639 Square Kilometers with a total population of around $300 \quad 000$ inhabitants. The estimated literacy rate of the district is $78 \%$ compared with $87 \%$ in the country as a whole. The total labour force in the district is around 118,000 and the unemployment rate is $9 \%$ (Hurelbrink, et. al., 1993). Monaragala District lies in the dry zone of the country of which $50 \%$ of land area receives less then 40 inches of rainfall.

A 'Pola' is an arena where a number of small business activities take place. "The main characteristic of a Pola is that a phenomenon of relatively small business activities takes place at a given time mutually from man to man" (Gomsen, 1985). However such business transactions occur through the Pola day / session, the business rises to its peak and swells with consumers during a particular time span.

Historically it has been the common place for buying their daily necessities. A Pola, in terms of marketing plays dual roles; as a first-hand-marketing outlet for producers and both wholesalers and retailers who directly bargain with consumers. Almost all the rural fairs function in above both ways while most of the urban fairs cater a wide range of consumer needs. Buyers and sellers meet each other at a regular place and most of these gatherings take place once or twice a week. Yet in some areas, they would take place more than twice a week (Senanayake, 1980).

\section{OBJECTIVE OF THE STUDY}

The main objective of this study is to identify the behavioral pattern of the fruit and vegetable consumers in Pola system in the Monaragala district in Sri Lanka and reasons for such behaviour. Influential reasons behind the consumer behavior pertaining to the fruit and vegetable market is focused in terms of the socio-economic characteristics, purchase pattern, perceptions and behavioral preferences of consumers in Pola system of the Monaragala district.

\section{METHODOLOGY}

Enabling quantitative and qualitative measures, both cross-sectional survey method and case studies were used. A structured questionnaire was designed and employed on the consumer at the "Pola" During the initial stages of the fieldwork. A representative simple random sample of hundred fruit and vegetable consumers were interviewed. Five of the 10 Divisional Secretariat Divisions within the district of Monaragala are represented in the study while considering one Pola from each Divisional Secretariat division. Monaragala, Dombagahawela, Buttala, Wallewaye and Medegama were the pola locations identified. Frequency Distribution, Chi-square Test were the 
statistical techniques applied in the quantitative analysis of data.

\section{RESULTS AND DISCUSSION}

\section{Consumer Sub-Sector}

In Business activities, there is transaction which is termed as receipt and payment; eventually at least, a buyer or seller must intervene to fulfill this activity. Therefore, when there are no buyers, no market is found. Sellers supply goods to the market when there is a demand for such commodity.

\section{Socio - economic characteristics of the consumers}

This section will focus on a review of the Socio-economic characteristics of the vegetables and fruit consumers in the study area, because it was proven by different studies that the characteristics such as the size of the family, the level of education, and occupational types are directly associated with the consumption level.

The age distribution and the family size of the consumers are shown in Figure 1 and 2 respectively. The major characteristics of the consumers who come to buy the farm produce at the Pola were that the majority $(75 \%)$ of the consumers relatively falls within the category above 51 years of age. Of the consumer families $70 \%$ constituted with $3-5$ members. This leads to rather a higher level of demand for vegetables and fruits within the study area.

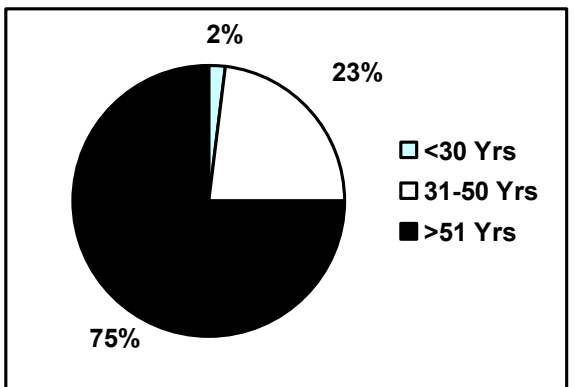

(Source: Field Survey)

Figure 01: Age composition of the consumers

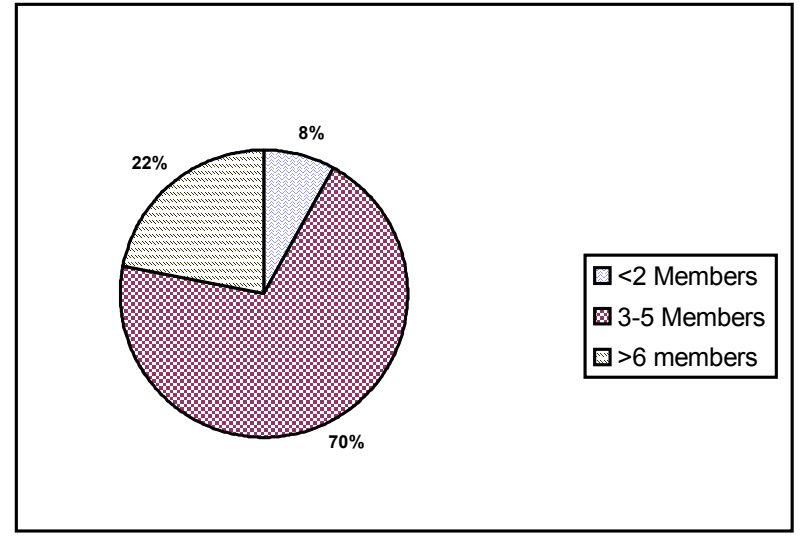

(Source: Field Survey)

Figure 02: Composition of Family Size of the Consumers 
It was found that $96 \%$ of the consumers at Polas in the Moneragala District were married. Of the consumers $58 \%$ were women. Two reasons are attributable to this aspect of behavior at the market. First, the female has a good experience about the domestic requirements, and secondly, the position she deserves in the village community regarding the income of the family. While the males of the family are toiling for the daily wage, the family has a bounden duty to spend that money frugally, and as such, she arrives at the market to fulfill that requirement of the family.

The educational background of consumers is presented in Figure 3. It is interesting to note that about $35 \%$ of the sample consumers in the Moneragala District were fairly educated, having obtained educational qualifications beyond the G.C.E. (O/L) which requires 11 years of schooling. Of the consumers in the sample $48 \%$ have obtained secondary school level education i.e. below or equal to G.C.E. $(\mathrm{O} / \mathrm{L})$. However, primary education receivers were $17 \%$ of the consumers in the sample.

The Occupation type is shown in Figure 4, which reveals that most consumers who came to buy commodities from the fairs (Polas) were farmers $(29 \%)$; laborers and teachers were $23 \%$; professional levels were $10 \%$ and traders and miscellaneous occupational levels were $38 \%$. They visit the market place for the purpose of buying their domestic requirements. It is clear that those who are engaged in different occupations visit the Pola to satisfy their daily needs, irrespective of their position in life. They come to the Pola because it is an exceptional marketing outlet.
It was found that most of these consumers $(49 \%)$ earned a monthly income of Rs. 5000-7000. They come under the category of middle income group, and $39 \%$ of the consumers received an income below Rs. 5000 . However, $12 \%$ of the consumers, who come under the higher income group (over Rs. 8000.00) came to Pola to get their provisions.

\section{Regular purchase pattern of the consumer at the pola}

The successful flow of marketing of the Pola system will depend on regular purchasing by the consumer which would, in turn, assist the progress of the inhabitants of the district socially, economically and financially. Regular purchasers are those who visit to the Pola to buy their provisions every Pola-day(every week) whereas irregular purchasers are those who do not. About $77 \%$ of the consumers of the Pola in the Monaragala District were regular purchasers.

The Table 1 shows the consumer behaviour of male and female in regular purchasing. $79.5 \%$ of males and $74.5 \%$ of the females were regular purchasers. According to these percentages of male and female consumers at the Pola, one cannot find a noticeable difference in consumer behaviour between males and females. At the same time, there was no significant relationship between gender and regular purchasing pattern at the 0.05 significant levels. However when there are more regular purchasers traders can build good relationship with consumers and it will be easy to identify and satisfy customers' needs and therefore it can lead to improve "Pola" system as an important marketing center for purchasing their provisions. 
Table 2 shows the relationship between age group and regular purchasing. Among the purchasers under 30 years of age, $78.3 \%$ were regular purchasers and $77.3 \%$ between $31-50$ years of age. However, this relationship is not significant at 0.05 level.

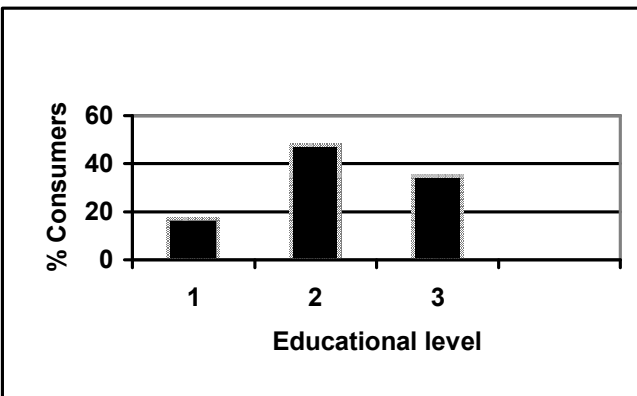

(Source: Field Survey)

$1=$ Primary $2=$ Secondary $3=$ Higher

Figure 03: Educational level of Consumers

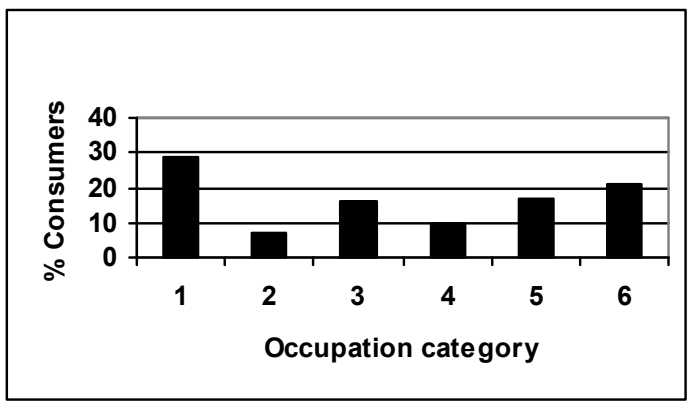

(Source: Field Survey)

$1=$ Farmers 2 -Laborers $3=$ Teachers $4=$ Professionals $5=$ Businessmen $6=$ Others

Figure 04: Consumer Occupation Pattern

Table 01: The Consumer Behavior of Male and Female in Regular Purchasing

\begin{tabular}{lcc}
\hline \multicolumn{1}{c}{ Sex } & Regular Purchase & Irregular Purchase \\
\hline Male & $35(79.5 \%)$ & $09(20.5 \%)$ \\
Female & $41(74.5 \%)$ & $14(25.5 \%)$ \\
\hline
\end{tabular}

(Source: Field Survey) $\quad\left(x^{2}=0.343, p>0.05\right)$

Table 02 : Relationship between age and Regular Purchasing

\begin{tabular}{lcc}
\hline \multicolumn{1}{c}{ Age Category } & Regular Purchase & Irregular Purchase \\
\hline Less than 30 years & $18(78.3 \%)$ & $05(21.7 \%)$ \\
31-50 years & $58(77.3 \%)$ & $17(22.7 \%)$ \\
Over 51 years & - & 01 \\
\hline
\end{tabular}

(Source: Field Survey) $\quad\left(\mathrm{X}^{2}=3.347, \mathrm{p}>0.05\right)$ 
Table 3 shows the relationship between occupation and regular purchasing. It was reveled that teachers $(100 \%)$, businessmen (94\%) and others- clerks, nurses, drivers, carpenters, were the most regular purchasers at the Pola.

It should be noted that, if they call at the Pola early, they would be able to purchase fresh and quality fruits and vegetables. The purchaser is compelled to call at the Pola early because they are in a position to buy any farm produce they need at a cheaper rate than at marketing outlets which are outside the Pola grounds. A large concentration of buyers and sellers makes a beneficial circumstance for the consumer as the basic laws of the competitive markets operate in this place of bargain. Farmers and laborers whose income is low, normally come at late hours and collect the leftover at cheaper prices.

Table 4 shows the relationship between education and regular purchase which reveals education as a factor for regular demand on commodities. Evidently, progress in education of the consumers, enhancing the occupational opportunities, shows a sharp increase in regular purchasers. The gradual increase in education means a gradual increase in regular purchase i.e. primary education $42.2 \%$, secondary education $76.6 \%$ and higher education $94.3 \%$.

The behavioral aspect of the consumer, regarding income and regular purchase is shown in table 5 .

Above patterns of purchasing could be analyzed as follows: $42 \%$ of the low income group was regular purchasers, $98 \%$ of the middle income group, and
$100 \%$ of the higher income group. As shown above, the accepted theory in economics could be applied here, that as income increases, and the demand for regular purchase is increased accordingly.

\section{Consumer perception on their market}

In most occasions (74\%) consumers decide on buying a particular vegetable/good at his/her arrival to the market place. They do not have prejudice decision. $72 \%$ of the consumers believed that market prices at the Pola were lower than other local market outlets. The presumption of $80 \%$ of the consumers was that the quality of goods reaching the Pola held as moderate quality. It is an accepted norm that quality is more important in fixing the sales price in the market.

The determination of the price depends on the supply of vegetables and fruits to the Pola. Generally, Monaragala District is gifted with a good source of wealth in farm produce throughout the year and $94 \%$ of the consumers believed that the produce was available throughout the year at the Polas.

These Polas create an intensive social change because people move here and there to get on with their transactions and other activities pertaining to their personal life. Also, through out the year traders are busy satisfying the needs of the consumers. $69 \%$ of the consumers bought vegetables and fruits at the Pola as their main purchasing item. They buy these items for a week's consumption. This is a cause for their regular visit to the Pola. However, only a few domestic items are bought at their local retail outlets. 
Table 03: Relationship between Occupation Type and Regular Purchasing

\begin{tabular}{lcc}
\hline \multicolumn{1}{c}{ Type of Occupation } & Regular Purchase & Irregular Purchase \\
\hline Farmers & $12(42.9 \%)$ & $16(57.1 \%)$ \\
Laborers & $03(42.9 \%)$ & $04(57.1 \%)$ \\
Teachers & $16(100 \%)$ & - \\
Businessmen & $16(94.1 \%)$ & 01 \\
Professionals & $09(95 \%)$ & 01 \\
Others & $20(90.9 \%)$ & 01 \\
\hline
\end{tabular}

(Source: Field Survey)

$\left(X^{2}=3.239, p>0.05\right)$

Table 04 : Relationship between Education and Regular Purchase

\begin{tabular}{lcc}
\hline \multicolumn{1}{c}{ Level of Education } & Regular Purchase & Irregular \\
Primary Education & $07(42.2 \%)$ & $10(58.8 \%)$ \\
Secondary Education & $36(76.6 \%)$ & $11(23.4 \%)$ \\
Higher Education & $33(94.3 \%)$ & 01 \\
\hline
\end{tabular}

(Source: Field Survey)

$\left(\mathrm{X}^{2}=18.097, \mathrm{p}<0.05\right)$

Table 05: Relationship between Income and Regular Purchase

\begin{tabular}{lcc}
\hline \multicolumn{1}{c}{ Income Level } & Regular & Irregular Purchase \\
\hline Less than 5000 & $16(42.1 \%)$ & $22(57.9 \%)$ \\
$5000-8000$ & $48(98 \%)$ & 01 \\
Over 8000 & $12(100 \%)$ & - \\
\hline
\end{tabular}

(Source: Field Survey)

$\left(X^{2}=41.569, \mathrm{p}<0.05\right)$

Table 06: Reasons for Preference on Market Sources

\begin{tabular}{clc}
\hline Priority & \multicolumn{1}{c}{ Reasons } & Percentage \\
\hline 1 & Low Prices & 40 \\
2 & Freshness & 34 \\
3 & Good quality & 47 \\
4 & High Degree of Selectivity & 30 \\
5 & High Accessibility & 79 \\
6 & Low Exposure to Chemicals & 30 \\
\hline
\end{tabular}

(Source: Field Survey)

(Multiple Column Response > 100) 
Table 6 shows the reasons for consumer preference on their market sources. According to the multiple responses of the respondents, the prior reason for their preference was the low price $(40 \%)$ followed by freshness (34\%), good quality (47\%) and high degree of selectivity $(30 \%)$, which was the sequential order of consumer priorities.

Although the priorities are given with reasons, it would appear that the consumers have no strong preference for one specific factor. However, they consider all the reasons given above when they buy goods at the Pola. They seem to be more concerned about quality of the vegetables and fruits rather than the low exposure to chemicals and the problem of accessibility. The survey has also revealed that $79 \%$ of the respondents were ready to pay higher prices for high quality produce.

It is evident from Table 7 that the consumer's main vegetable market source was the Pola $(97.9 \%)$. The next was the village retailer $(65.5 \%)$. Thus, most of the consumers seem to be more interested in buying vegetables at the Pola and at the village retailers. It was found during the survey that $83 \%$ of the respondents had special preference for Polas due to the reasons of low price, selectivity, abundance of variety, ability to bargain, availability of a wide selection under one roof, freshness of vegetables and fruits which are not available in their home vicinity.

Table 8 shows the factors of influencing the price of farm produce.
According to the multiple responses given by the respondents, the main factor that caused price increase for farm produce at the Pola was the low supply $(74.7 \%)$ followed by seasonal problems $(58 \%)$, high quality $(62 \%)$ and low bargaining power (42\%). During the seasons the vegetable and fruit supply decreases and that results in the increase of price.

As shown in Table 9, consumers' first priority in buying vegetables and fruits is price $(56.8 \%)$. Their next considerations are appearance (52\%), freshness $(40 \%)$, and nutritive (42.4\%) respectively. As it was shown earlier, consumers were interested in both price and quality (appearance, freshness, and nutritive value) when they purchase vegetables and fruits.

Table 10 provides information on consumers' vegetable purchase at the Pola. It reveals that most of the vegetables purchased by the consumers were of moderate quality and the average quantity purchased was around $500 \mathrm{~g}$. of each vegetable. Apart from lime and banana other fruits bought at the Polas in the Moneragala District are quantitatively less. It is interesting to note that among the consumers in urban area, the consumption of upcountry vegetable is highest and it makes a higher demand on them for the simple reason that they feel it easy to prepare and add quality to their lunch packets. The consumers in rural areas consume more low country vegetables and less up-country vegetables thus making a low demand for the produce from up-country. 
Table07: Vegetable Market Sources

\begin{tabular}{clc}
\hline Priority & Markets & Percentage \\
\hline 1 & Pola / Weekly Fair & 97.9 \\
2 & Village Retailer & 65.5 \\
3 & City/Main Market & 71 \\
4 & Super Market & - \\
\hline
\end{tabular}

(Source: Field Survey)

(Multiple Column Response $>100$ )

Table 08: Factors of Influencing the Price of Farm Produce at the Pola

\begin{tabular}{clc}
\hline Priority & \multicolumn{1}{c}{ Factors } & Percentage \\
\hline 1 & Low Supply & 74.7 \\
2 & Seasonal Problems & 58 \\
3 & High Quality & 62 \\
4 & Low bargaining Power & 42 \\
5 & High Demand & 33 \\
6 & Government Trade Policies & 50 \\
\hline
\end{tabular}

(Source: Field Survey)

(Multiple Column Response > 100)

Table 09: Consumer Considerations in Buying at Pola

\begin{tabular}{clc}
\hline Priority & \multicolumn{1}{c}{ Consideration } & Percentage \\
\hline 1 & Price & 56.8 \\
2 & Appearance & 52 \\
3 & Freshness & 40 \\
4 & Nutritive Value & 42.4 \\
5 & Organic Vegetable / Low & 62.7 \\
& Exposure to Chemicals & \\
\hline
\end{tabular}

(Source: Field Survey)

(Multiple Column Response $>100$ )

Table 10: Purchase Information of Consumers of a Previous Pola Day

\begin{tabular}{ccccc}
\hline Produce & $\begin{array}{c}\text { Average } \\
\text { Quantity } \\
\text { Purchased }(\mathrm{kg})\end{array}$ & $\begin{array}{c}\text { Average } \\
\text { Minimum } \\
\text { Price per kg }\end{array}$ & $\begin{array}{c}\text { Average } \\
\text { Maximum } \\
\text { Price Per kg. }\end{array}$ & Quality \\
\hline Beans & 0.4918 & 40.33 & 55.48 & Moderate \\
Brinjals & 0.5217 & 20.46 & 30.04 & Moderate \\
Beet & 0.4695 & 40.20 & 50.15 & Moderate \\
Carrot & 0.4250 & 42.00 & 53.80 & high \\
Potatoes & 0.6523 & 41.27 & 60.53 & Moderate \\
Tomatoes & 0.4957 & 38.55 & 49.59 & Moderate \\
\hline (Source: Field Survey) & & &
\end{tabular}




\section{CONCLUSION}

Socio-economic characteristics of the consumers are directly associated with the consumption level of vegetable and fruits in the study area. The majority of consumers who come to buy the farm produce at the Pola relatively falls within the category above 51 years of age, with a substantial level of education. Most of those who come to buy goods are females. It is reveled that teachers, clerks, nurses, carpenters and drivers are the most regular purchasers at the Pola. About $77 \%$ of the consumers of the Pola in the Monaragala district were regular purchasers.
Most of the Consumers do not have predetermined preferences and it is apparent that the consumers decide on items of purchase at the point of arrival to the Pola. Majority of the consumers believed that market prices at the Pola were lower than other local market outlets and the quality of goods reaching the Pola held as moderate quality. The main reason for their preference for such market (Pola) was the low price fallowed by the other considerations such as freshness, good quality and high degree of selectivity. Consumers were interested in both price and quality (appearance, freshness and nutritive value) when they purchase vegetables and fruits.

\section{References}

Central Bank of Sri Lanka (Various issues), (1986/87): Consumer Finance survey, Central Bank of Sri Lanka, Colombo, pp10 - 12.

Food and Agriculture Organization of the United Nations(1989), Horticultural Marketing, Agricultural service Bulletin 76, Rome pp 1-55

Gormsen, E., (1985); The Role of Market Places in Developing Countries in ICRISAT (ED), Agricultural Markets in the Semi - Arid Tropics, India, pp. $121-130$.

Hurelbrink, R.L., G.A. Marlowe, \& J.R. Ross, (1993): Role of Public and Private Sector in Horticultural Development: Uva Province, Diversified Agricultural

Research Project, Development Alternatives INC., Department of Agriculture, Preadeniya, pp. 16-31.

Rupasena, L.P., (1999): Production and Marketing of Vegetables, Research study No. 102, ARTI, Colombo, pp. 1 - 7

Senanayake, S.P.M., (1980): Periodic Rural Markets in the Kurunegala District, Occasional Publication 18, HARTI, Colombo, pp 16 - 18. 